\author{
WOJCIECH GÓRALSKI \\ University of Cardinal Stefan Wyszyński, Warsaw, Poland \\ (D) https://orcid.org/0000-0001-6548-4120
}

\title{
Diocesan Synod Today In What Shape?
}

\begin{abstract}
The Second Vatican Council shaped a new model for a diocesan synod, which was adopted, among others, in Poland, and is characterised by a departure from making the norms of particular law and the popularisation of the council teaching in particular Churches. On the other hand, after the promulgation of the new Code of Canon Law in 1983, the diocesan synods adjusted the diocesan law to the code norms. When this period of the reception of the code law to the diocesan legislation achieved its result, the final resolutions of the subsequent diocesan synods, which were usually extensive, do not meet - to a large extent - the requirements set by the documents of the Holy See: Instruction of the Congregation for Bishops and the Congregation for the Evangelisation of Nations of 1997 and the Directory of the Congregation for Bishops Apostolorum successores of 2004. The author calls for the use of these enunciations so that diocesan synods can be an effective tool for the renewal of a particular Church.
\end{abstract}

Keywords: diocesan synod, legislation, synodal resolutions, diocesan bishop

If the concept of Ecclesia semper reformanda is still topical, and undoubtedly it is, then the institution of a synod has also not lost any of its topicality. Since the first centuries of the Church's existence, it has constituted a well-tested tool of Church reform and rejuvenation. ${ }^{1}$ It was confirmed by the Second Vatican Council, ${ }^{2}$ which also initiated a new era

${ }^{1}$ See M. PIstocchi: De synodo diocesana. Taurini 1922, p. 9.

2 The Council expressed its wish that the "honourable institutions of Synod and Council obtain more power, which would contribute more properly and effectively to a better response to the decrease in the number of faithful and the observance of obedience in various Churches, suitable to the circumstances." Dekret o pasterskich zadaniach 
in the history of synodal assemblies. Post-conciliar synods, both particular (plenary and provincial) as well as diocesan, which are shaped in the spirit of the Vatican II doctrine, in contrast to the traditional synods, are characterised by a more pastoral dimension of their end resolutions, the participation of lay people in the proceedings and the way a synod is prepared, as well as its duration. ${ }^{3}$

When it comes to diocesan synods, which were introduced in Poland in the mid-13th century, constituted a significant factor for implementing reforms in specific dioceses (done, first and foremost, through codifying its own specific law) for many centuries. However, after the Second Vatican Council, similarly to other countries, they gained a more pastoral character and became channels through which the conciliar teaching could reach the vast circles of clergy and lay followers. In this way, the conciliar message found its application in undertaking various pastoral activities within the area of the respective Churches. ${ }^{4}$ The synodal resolutions, which are very often exceedingly spacious, and in which a broad vista of thematic threads were included, constitute some of the valuable achievements of the conciliar thought that was adopted by these Churches. ${ }^{5}$

This profile of pastoral diocesan synods changed the very moment that Pope John Paul II promulgated the new Code of Canon Law on January $25,1983 .{ }^{6}$ This event - for understandable reasons - could not

biskupów w Kościele “Christus Dominus”, no. 36. In: Sobór Watykański II. Konstytucje, Dekrety, Deklaracje. Tekst polski. Pallotinum 1967.

3 See E. Sztafrowski: "Synod diecezjalny w doktrynie soborowej i jej wyraz w posoborowych synodach polskich.” Prawo Kanoniczne 30 (1987), no. 1-2, p. 62; J. Gręźlikowski: "Instytucja synodu diecezjalnego w Kościele w Polsce po Soborze Watykańskim II." Studia Włoctawskie 4 (2001), pp. 107-109; W. GórAlSKI: Wprowadzenie do historii ustawodawstwa synodalnego w Polsce. Lublin 1991, p. 249; Idem: "Czy synody są nadal szansą dla Kościoła?" Homo Dei 61 (1992), no 1-2, p. 3; IDEM: “Instytucja synodu w Kodeksie Prawa Kanonicznego Jana Pawła II.” Prawo Kanoniczne 31 (1988), no 3-4, pp. 35-44.

${ }^{4}$ W. GóRAlSKI: "Ecclesia semper reformanda. W nurcie synodów polskich - wczoraj i dziś.” In: Oddanie i wytrwałość. Recepcja II Polskiego Synodu Plenarnego. Eds. W. GóRALSKI, H. SEWERYNIAK. Warszawa 2004, p. 61.

${ }^{5}$ The following diocesan synods should be mentioned: Włocławek (1967), Poznań (1968), Gdańsk (1973), Warszawa (1971-1974), Katowice (1972-1975), Kraków (1972— 1979) and Gnieźno (1978-1981). See. T. Pieronek: "Posoborowe synody diecezjalne w Polsce." In: Stużyć Prawdzie i Miłości. Pamięci Księdza Biskupa Dr. Stefana Baryty, III Ordynariusza Częstochowskiego. Ed. J. Kowalski. Częstochowa 1984, pp. 392-412; W. Góralski: "Ruch synodalny w Polsce po Soborze Watykańskim II.” Roczniki Nauk Prawnych 8 (1998), pp. 140-151.

${ }^{6}$ CODEX IURIS CANONICI auctoritate Ioannis Pauli PP. II promulgatus. AAS 75/ II (1983); Polish text: Codex Iuris Canonici auctoritate Ioannis Pauli PP. II promulgatus. Code of Canon Law. Polish translation was approved by the Episcopal Conference of Poland. Pallotinum 1984. 
remain without impact on the further course of synodal activity in specific Churches, especially since this codification (in force from 1983), as the very Legislator defined it in the Pastoral Constitution Sacrae discipline leges, constituted the new Code "as some sort of complement of the teachings of the Second Vatican Council." Apart from that, the new Code of Canon Law legitimised the basic structure of the diocesan synod (can. 460-468) together with specifying the form of the final synodal documents (declarations and synodal decrees). It is no wonder then that the diocesan synods that were initiated during that period concentrated on the reception of code norms first by updating their own particular laws. ${ }^{8}$

When the new 1983 CIC instructions were considered by the synodal legislatures of specific dioceses, the concluding resolutions of the newest synodal assemblies seemed to have been returning to the post-conciliar model, in which the legal norms only constituted an insignificant area, in their profiles.

When discussing diocesan synods today, it seems suitable to, first and foremost, present the status iuris of this institution as defined not only in the CIC, but also in the subsequent documents of the Holy See and then to show the character of the end resolutions of the Polish synods after the publication of the new CIC and of the already mentioned post-synodal documents, in order to identify the expectations from the subsequent synodal assemblies.

${ }^{7}$ Ibidem, p. 13.

8 The following diocesan synods should be mentioned: Częstochowa (1976-1986), Lublin (1977-1985), Gniezno (1981), Tarnów (1981-1986), Kielce (1983-1991), Włocławek (1985-1991), Wrocław (1985-1994), Koszaliń-Kołobrzeg (1986-1990), diocese in Lubaczów (1987-1990), Płock (1987-1991), Białostok (1991-2000), Poznań (1992-1993), Pelpliń (1992-2000), Drohiczyn (1994-1997), Łowicz (1995-1999), Przemysl (1995-2000), Gniezno (1995-2000), Łomża (1995-2005), Łódz (19961998), Sandomierz (1996-1999), Zamość—Lubaczów (1996-2001), Ełk (1997-1999), Warszawa-Praga (1998-2000), Warszawa (1998-2003), Radom (1999), Pelplin (1999-2000), Gdańsk (2001), Rzeszów (2001-2004), Sosnowiec (2001-2004), Opole (2002-2005), Poznań (2004-2008), Warmia (2006-2012), Kalisz (2007-2009), Toruń (2007-2011), Legnica (2007-2012), Płock (2012-2015); synods in progress: Radom (since 2008), Zielona Góra-Gorzów (since 2017), Siedlce (since 2012), Katowice (since 2012), Opole (since 2015), Koszalin-Kołobrzeg (since 2016), Tarnów (since 2016), Elbląg (since 2016). See W. Góralski: “Charakterystyka i ocena II Polskiego Synodu Plenarnego i współczesnych synodów diecezjalnych w Polsce.” In: II I Polski Synod Plenarny a synody diecezjalne. Eds. J. Krukowski, M. Sitarz, A. Pastwa. Lublin 2015, pp. 24-26. 


\section{Diocesan Synod in CIC and in the post-Code documents of the Holy See}

A new regulation was introduced pursuant to Directive no. 36 of the Christus Dominus Decree (in the hope that the honourable institutions of the Synod and Council could obtain more power, which would contribute more appropriately and effectively to a better response to the decrease in the number of the faithful and the observance of obedience in various Churches, which were suitable to the circumstances) as a part of the postsynodal CIC.

At this point, it seems important to remark that ten years before promulgation of the new Code, on February 22, 1973, the Congregation of the Bishops issued an Ecclesiae imago instruction concerning the topic of the pastoral service of bishops, ${ }^{9}$ a fragment of which was dedicated to the diocesan synod (nos. 163-165). Here, the attention was focused on the objectives of that meeting (supporting the diocesan bishops in delineating the way to perform pastoral work in a diocese, solving difficulties concerning preaching and managing, triggering the actions of a general character and correcting any possible mistakes in the areas of doctrine and customs). What was also emphasised was the need to correctly prepare synods and organise its work, which also included the lay followers and monastic representatives in the synod as well as trying to spread interest regarding the synod among the common followers. Finally, several remarks were offered that discussed the way of conducting a synod (preceding the sessions with a liturgical service, especially the Eucharist, freedom of synodal debates over the projects of end resolutions with the active participation of a bishop, putting the resolutions into force and promulgating them only by the bishop).

The 1983 CIC defines a diocesan synod as an "assembly of the chosen reverends and other faithful of a particular Church, who for the good of the entire diocesan community support the diocesan bishop" (can. 460). The synodal assembly is, therefore, a form of cooperation between the representatives of a diocesan presbytery and laity with their bishop who, however, is the only legislator during the synod and signs the synodal

9 Sacra Congregatio pro Episcopis: Directorium de pastorali ministerio "Ecclesiae imago" (22.02.1973), Typis Polyglottis Vaticanis 1973; Polish text: Kongregacja BISKUPów: Dyrektorium Ecclesiae imago na temat pasterskiej posługi biskupów. In: Posoborowe prawodawstwo kościelne (dokumenty prawno-liturgiczne). Prep. E. SzTafrowski, v. 6, p. 1. Warszawa 1975, pp. 15-352 and in: Ustrój hierarchiczny Kościoła. Wybór źródet. Ed. W. KacPrzyK, M. Sitarz. Lublin 2006, pp. 403-516. 
declarations and decrees; all of the other participants have an exclusively advisory voice (can. 466). ${ }^{10}$

The question of how often a synod should take place was left to the diocesan bishop by the Legislator, when appropriate to the circumstances and while making the decision he should consult the Presbyterian Council (can. $461 \S 1$ ). It is also diocesan bishop's task to convene a synod and to preside over it with the possibility of delegating a general curate or bishop's curate to specific sessions (can. 462 \$ $1-2$ ).

When it comes to the participants, can. $463 \S \S 1-2$ provides three categories of individuals (ex officio, out of choice, and nominated), which span both the clergy and laity as well as members of the consecrated life institutions; at the same time, it precisely defines the method for selecting the remainder of members. Moreover, it provides the possibility of inviting people who belong to different Churches or church communities that do not maintain full unity with the Catholic Church (can. 463 \$) to the synod (only in the capacity of observers). A member of the synod who faces some difficulties cannot be substituted for by someone else (can. 464). The order in which the topics that are suggested during the synod should be subjected to a free discussion during the synodal sessions is also significant (can. 465). What is of a more formal nature is the regulation regarding the obligation of a diocesan bishop to submit the content of any synodal declarations and decrees to the metropolitan and the Episcopal Conference (can. 467), which is similar to the norm that allows a diocesan bishop to suspend or dissolve a diocesan synod (can. 468 § 1) or the decision that should a Bishop's post be vacated, or should there be an obstacle in its functioning, the synod is to be suspended until a new diocesan bishop issues a recommendation to continue it or deems it to be terminated (can. $468 \S 2$ ). ${ }^{11}$

Regarding the CIC norms, on July 7, 1997, the Congregation for Bishops and Congregation for the Evangelisation of Peoples published an Instruction regarding diocesan synods: De synodis dioecesanis agendis (signed on March 19, 1997), which is binding for those syn-

10 See M. Sitarz: "Podstawowe zasady w sprawowaniu władzy ustawodawczej biskupa diecezjalnego." In: II Polski Synod Plenarny a synody diecezjalne. Eds. J. Krukowski, M. Sitarz, A. Pastwa. Lublin 2015, pp. 95-97; F. Coccopalmerio: "Il sinodo diocesano (can. 460-468)." In: Raccolta di scritti in onore di Pio Fedele. Perugia 1984, pp. 407-408.

${ }^{11}$ See W. Wójciк: "Synod diecezjalny w nowym Kodeksie Prawa Kanonicznego." Prawo Kanoniczne 29 (1986), no. 1-2, pp. 93-122; W. GóRALsKI: „Instytucja synodu w Kodeksie Prawa Kanonicznego Jana Pawła II.” Prawo Kanoniczne 31 (1988), no 3-4, pp. 35-44; IDEm: "Synod diecezjalny narzędziem odnowy i reformy Kościoła partykularnego.” Kronika Diecezji Sandomierskiej 89 (1996), pp. 477-479. 
ods that were to commence three months after the publication of the document. $^{12}$

This lengthy enunciation, which was carefully prepared by the already mentioned curia dicastery, ${ }^{13}$ which outlines the correct way for applying the code norms, firstly presents the nature and purposefulness of a diocesan synod, where any forms of setting the synod against the bishop, who is the only legislator in his particular Church, are deprecated and which also accentuates the community-creating character of a synod. The document then discusses the content of a synod, suggesting a canonical way to select the members of a synodal assembly. What constitutes a novelty here is an instruction according to which the person whose opinion differs from the Church's doctrine or who declines the authority of a bishop should be deprived (by the means of a bishops' decree) of the possibility to participate in a synod. What is also a novelty is the possibility for the diocesan bishop to summon all priests to a synod if a given diocese enjoys a significant number of these. ${ }^{14}$

The issue of summoning individuals to and preparing a synod was also mentioned (summoning, preparation committee and synod regulations, specific preparatory stages). Before a synod is summoned, the Presbyterian Council should be asked and any information that a bishop gathers when visiting a given diocese has to be considered. The bishop should form a preparation committee (it should include experts in the field of canon law) and a synod secretary's office. The regulations should, first and foremost, define the composition of the synod, the way in which the election of the participants to the synodal assembly, offices and synodal committees will be conducted, as well as the course of the synodal sessions (among others, concerning speaking out about various matters and voting). When it comes to the specific preparatory stages, the Instructions assume a spiritual, catechistic, and informational preparation (first stage); a diocesan consultation that makes it possible for the followers to present their needs and postulates within the area of the topic of the synod (second stage) and the bishop specifying the issues to be considered during the synod, among others, with the possibility of outlining the synodal

12 Congregatio pro Episcopis, Congregatio pro Gentium Evangelizatione: De synodis dioecesanis agendis Instructio (7.07.1997), AAS 89 (1997), pp. 706-727.

${ }^{13}$ See A. Longhitano: "I sinodi regionali e diocesani: esperienze e prospettive." In: La sinodalité la participation au gouvernement dans l'Église. Actes du VII Congrès International de Droit Canonique, Paris, Unesco, 21-28 septembre 1990, L'Anné Canonique, hors série (1990), v. 2, p. 615.

${ }^{14}$ Congregatio pro Episcopis, Congregatio pro Gentium Evangelizatione: De synodis..., nr I-II; See T. Tozkrut: "Nowa Instrukcja o synodach diecezjalnych." Prawo Kanoniczne 42 (1999), no. 1-2, pp. 146-151. 
documents with divisions into the specific matters as well as a theological and canonical introduction (third stage). ${ }^{15}$

The next part of the document was dedicated to the course of a synod, where attention was paid to conducting the synodal sessions (connected with the synodal liturgy), in particular, in the fundamental moments of the assembly (among others, opening and concluding). It was recommended that the synodal sessions, at least the most important ones, take place in a cathedral. At the same time, it was stressed that the participants to the synod must deliver a confession of faith according to can. 833. It was also explained that a bishop should familiarise himself with the suggested topics, eliminating any that are inconsistent with the Church's doctrine or the Papal Magisterium, or any that concern a matter that is restricted to a different entity (e.g. the Holy See). It was also emphasised that a bishop should listen attentively to the opinions of the participants of the synodal assembly and to assess them according to his own conscience, and then to subsequently issue the appropriate instructions to the committees that are editing the end resolutions. It was emphasised at the same time that these end resolutions should be formulated quite precisely (rather than broadly), so that they could become "a pastoral guide in the diocese." What constitutes a novelty is the instruction according to which the decision of a bishop to suspend or dissolve a synod (can. 468) should be consulted with the Consilium Presbyterale. ${ }^{16}$

The last issue in the document concerned the end resolutions of the synod - the synodal declarations and decrees. The introduction itself contains a statement that suggests that the types of resolutions that are mentioned, on the one hand, are about actual legal norms, which might be referred to as "constitutions" or are an indication of decisions that were binding in the past, while on the other hand, they might be about unambiguous statements regarding the truth about the doctrine of faith or the doctrine of Catholic morality, first and foremost, in these matters, which refer to the life of a particular Church. ${ }^{17}$

What should be deemed significant was the decision to leave the signing of any synodal declarations and decrees to the diocesan bishop, since only (as the sole legislator in a diocese) he is their author, which is expressed in the Instruction. Therefore, the document prohibits publishing - as synodal - the documents that have not been signed by a bishop. At the same time, it remarks that through the synodal decrees, a bishop recommends their preservation as canonical norms, which standardise

15 Congregatio pro Episcopis, Congregatio pro Gentium Evangelizatione: De synodis..., no. III; T. Tozkrut: Nowa Instrukcja..., pp. 151-152.

16 Ibidem.

17 Ibidem, p. 153. 
diocesan life within the areas that the law entrusts him with and adapts the general Church discipline to the specificity of a particular Church. It also adds that the law stipulates that a synodal decree against the rights of a superior would be invalid, that is the law of the common Church, general decrees of particular synods and the Conference of Bishops, as well as assemblies of the Church province bishops within the area of their authority. ${ }^{18}$

Subsequently, the instruction, which was included in can. 467, ordered a diocesan bishop to inform the Metropolitan and the Episcopal Conference about any synodal declarations and decrees; the Instruction emphasises that the objective here is to strengthen the community of the episcopate and to create normative harmony in the Churches of the same region. ${ }^{19}$ It is also recommended - as the novum constitutes - that these synodal documents (by the papal legate) also be sent to the Congregation for Bishops or the Congregation for the Evangelisation of Peoples, and the Instruction includes a statement that suggests that the documents will appropriately studied there. ${ }^{20}$

What also constitutes a novelty of the Instruction is the recommendation that should the synodal documents, and first and foremost, synodal decrees not include an order to execute them, it shall be the diocesan bishop's decision, after concluding the synod, to determine how to execute them, which might be entrusted to some diocesan offices. ${ }^{21}$

A supplement was attached to the Instruction in which the matters concerning teaching, sanctifying, and pastoral service in the area of which, according to CIC, the diocesan bishop is competent were presented. ${ }^{22}$

In turn, the Congregation for Bishops, on February 22, 2004, issued a Directory entitled Apostolorum successores on the pastoral service of bishops ${ }^{23}$ in which it stresses the privileged place of a synod among

${ }^{18}$ Cf. can. 135 § 2 CIC.

${ }^{19}$ Congregatio pro Episcopis, Congregatio pro Gentium Evangelizatione: De synodis..., no. $\mathrm{V}, 4$.

${ }^{20}$ Ibidem, no. V, 5.

${ }^{21}$ Ibidem, no. V, 6.

22 Ibidem. Pastoralia munia quae Codex Iuris Canonici concredit legum ferendarum potestati Episcopi dioecesani; the possibility to make specific laws by diocesan bishops was emphasised by, among others, E. CORECCO in his work: Ius universale - ius particolare. In: Ius in Vita et in Missione Ecclesiae. Acta Simposii Internationalis Iuris Canonici occurente X Anniversario Promulgationis Codicis Iuris Canonici Diebus 19-24 Aprilis 1993 in Civitate Vaticana Celebrati. Libreria Editrice Vaticana 1994, p. 573.

${ }^{23}$ Congregatio pro Episcopis: Direttorio per il ministero pastorale dei vescovi „Apostolorum Successores" (22.02.2004). Città del Vaticano 2004; Polish text: Congregation FOR BISHOPS: Dyrektorium „Apostolorum successores” o pasterskiej postudze biskupów. In: Ustrój hierarchiczny Kościoła. Wybór źródeł. Ed. W. KacPrzyK, M. Sitarz. Lublin 2006, pp. 517-711. 
the structures that helps bishop to manage a diocese, quotes the definition of this institution and acknowledges a synod to be a "suitable place of adaptation of laws and norms of the common Church to a specific diocesan situation." ${ }^{24}$ Subsequently, the composition of the synod was mentioned (as a representation of the diocese), the possibility of observers from different Churches to participate in a synod, the rights and obligations of a bishop in a synod, preparation of a synod and its course. ${ }^{25}$ The disposition of the 1997 Instruction of the Congregation for Bishops and Congregation for the Evangelisation of Peoples repeats the recommendation that a bishop also needs to send the final synodal documents (resolutions) to any "interested dicasteries of the Holy See, especially to the Congregation for Bishops and Congregation for the Evangelisation of Peoples." 26

\section{The character of the most recent synods concluded after the promulgation of the new CIC and the issuance of the postcode documents}

The delineation by the 1983 CIC and post-Code documents of the Holy See (De synodis dioecesanis agendis Instruction from 1997 and the Apostolorum successores Directory from 2004) of a new model for diocesan synods imposed the obligation to comply with the new regulation, among others, with reference to the shape of the final synodal resolutions, on diocesan bishops. Indicating "the synodal declarations and decrees" (can. 466), the aim of the Legislator seemed to have been to end some solutions that, very often, were of an experimental nature. ${ }^{27} \mathrm{He}$ unambiguously claimed that synodal resolutions should not be restricted exclusively to quoting conciliar documents, acknowledging facts and describing situations, postulates, and initiatives. What is also meaningful within this area is the mentioned disposition of the 1997 De Synodis dioecesanis agendis Instruction on the need to make legal norms at

${ }^{24}$ Ibidem, no. 169.

${ }^{25}$ Ibidem, no. 168 and $170-175$.

${ }^{26}$ Ibidem, no. 175.

27 See W. Góralski: "Instytucja synodu w Kodeksie Prawa Kanonicznego...," pp. 35-44; G. Corbellini: Il sinodo diocesano nel nuovo Codex Iuris Canonici. Roma 1986, pp. 146-157. 
a synod. It is not without a reason that the Supplement attached to the document includes the presented issues that the CIC recommends be regulated by a bishop. ${ }^{28}$

An analysis of the end resolutions of particular diocesan synods, which were concluded within the mentioned period, makes it possible to acknowledge that - in contrast to the post-conciliar synods that were concluded before the new CIC was promulgated - are, as a rule, characterised by a quite wide reference to this codification, which should be accepted as a fully understandable and appropriate phenomenon.

Strictly legislative decisions of synodal assemblies are, first and foremost, included in the so-called statute section, which is usually the first one; moreover, as a rule, they are included in the long appendices. Since, apart from the stricte (as understood through the prism of can. $8 \S 2$ ), the resolutions of synods include general decrees (as understood through the prism of can. 29), therefore, are the so-called dispositions, including the general rules that regulate a specific matter (not expressed once); such decrees are acts in the strict meaning of this word. Apart from that, it is also possible to encounter general executive decrees in synodal resolutions, in which the means for applying an act are defined more precisely or which include a request to adhere to a given act (can. $31 \S 1$ ). It has to be said that these decrees are issued by the executive power, and therefore, they are not acts because their only aim is to exclusively implement the acts. $^{29}$

Among synod resolutions it is also possible to find normative acts that can be defined as instructions. Therefore, it seems important to clarify that according to can. $34 \S 1$, an instruction is an executive power act that explains the regulations of the acts and also reveals and defines the arguments that have to be considered when observing them; these are issued for those who are obliged to implement the acts. Meanwhile, the term "instruction" that appears in the synodal resolutions, de facto means a general decree (as specified by can. 29); hence, it has the character of an "act." 30

What is characteristic of synodal documents are the various statutes and regulations for legal entities (e.g. chapters, seminaries, associations, etc.) as well as for various bodies that do not have a legal personality (e.g. Consilium Presbyterale, Diocesan Pastoral Council, Parish Council, etc.).

${ }^{28}$ W. Góralski: “Sprawowanie władzy ustawodawczej przez biskupów...," pp. 24-25; IDEM: Charakterystyka i ocena..., pp. 43-44.

${ }^{29}$ See R. Sobański: Nauki podstawowe prawa kanonicznego. Teoria prawa kanonicznego, v. 1. Warszawa 2001, pp. 42-45; W. GóRALSKI: "Sprawowanie władzy ustawodawczej przez biskupów...," pp. 24-25.

${ }^{30}$ W. GóRALSKI: “Charakterystyka i ocena...," p. 45. 
According to can. $94 \S 1$, statutes in their correct meaning are ordinances (collections of regulations) that are issued according to the law for groups of people or objects and define their goal, tasks, structure, management, and means of functioning. In $\S 3$ of this canon, the regulations concerning acts are adapted to the statute regulations that are created by the executive power. In the meantime, the rules and regulations such as the disciplinary regulations (sets of norms that are binding during the assemblies that are convened by the Church authorities or as a result of the initiative of the followers due to various celebrations), define everything that concerns establishing assemblies and supervising the way they work (can. 95 $\S 1$ ). Even though the disciplinary regulations are not used for regulations that refer to acts, when these are announced by the appropriate executive power, they can obtain the character of an act. ${ }^{31}$

Considering the character of the specific types of normative acts that belongs - pursuant to the Code regulation - to their essence, and that refers to the particular elements of the synod resolutions, a variety of terminology is used, which does not always match the Code definitions, which establish the qualifications of synodal resolutions according to the names and definitions they were given, but instead according to their real character, which they are characterised by, should be perceived to be correct. ${ }^{32}$

When we consider the specific categories of synodal resolutions, we can observe that a great deal of space is dedicated to executive decrees, which are the legal acts by means of which the legislators define the way code norms should be implemented more precisely and also encourage us to follow them. This seems justified since the reception of the code norms in a synodal legislation constitutes a crucial objective that is undertaken by synods. In the statutes of many synods, it is explicitly stressed that for more important issues - for practical reasons - the resolutions that are adopted by synodal assemblies refer to the CIC norms. In some cases, it is possible to find an indication of the relevant canon (or canons) of the Code next to the reference, in other cases, we can find the quoted content of a given instruction of common law. There are also synods which, as a rule, do not refer to code canons, but limit themselves to exclusively considering their instructions. ${ }^{33}$

31 See T. Pawluk: Prawo kanoniczne wedtug Kodeksu Jana Pawła II, v. 1: Zagadnienia wstępne i normy ogólne. Olsztyn 1985, p. 248; E. SzTafrowski, Podręcznik prawa kanonicznego, v. 1. Warszawa 1985, p. 211; W. Góralski: “Sprawowanie władzy ustawodawczej przez biskupów...," p. 25.

${ }^{32}$ Ibidem, pp. 25-26; See R. Sobański: Nauki podstawowe..., p. 53.

33 W. Góralski: “Charakterystyka i ocena...," p. 45. 
When it comes to cases of defining the means of applying the relevant code rules more precisely, the decision of the synodal statutes relates to a great many areas of life. For instance, many synods, when defining with greater precision the way can. $222 \S 1$ (on the obligation of the faithful to redress the needs of Church) should be implemented, indicate when and for what purposes contributions (contribution plate and collection boxes) are to be collected in a given diocese. A different example can be the fact that a synod defines a specific date for submitting the annual report on managing the parish property, which constitutes a more specific application of can. $1287 \S 1$, which is similar to the precise - in relation to can. $1281 \S \S 1-2-$ synodal decisions regarding the alienation of Church property. ${ }^{34}$

It is easy to see that the general executive decrees defining the means of implementing the code norms more precisely include numerous statutes of diocesan institutions and instructions also contained in the socalled annexes which are an integral part of synodal resolutions. ${ }^{35}$

Synodal legislators, who are urged to observe the code norms, use the form of literal quotation or a paraphrase of a given code canon (along with indication clear reference to it) as well as formulating norms in the spirit of a given canon, accompanied only by a general reference to the provisions of canon law. ${ }^{36}$

In other cases, we encounter a general disposition that recommends the observance of norms in a specific field, for instance, procedural law or criminal law. ${ }^{37}$

Undoubtedly, a special and significant place in the resolutions of the diocesan synods is occupied by particular acts in the strict sense of the term and by general decrees (so-called resolutions) such as the acts proper, both of which adapt the diocesan law to the norms of the code. It is not easy to precisely distinguish between the two in specific cases. By adopting laws and general decrees, the synodal legislators regulate the entirety of the matters concerning their own particular Churches. These types of normative acts are in conformity with the provisions of the CIC and therefore constitute particular law of the iuxta legem communem. ${ }^{38}$

In an attempt to undertake a concise characteristics of the acts and simultaneous general decrees that are present in synodal resolutions, we should first say that some of them are, to a large extent, similar in terms

\footnotetext{
${ }^{34}$ Ibidem, pp. 45-46.

35 Ibidem, p. 46.

${ }^{36}$ Ibidem.

37 Ibidem.

${ }^{38}$ Ibidem, p. 47.
} 
of the solutions regarding specific areas or issues. It even appears that some statements are, sometimes literally, taken over or adopted by one or more synods from another, previously held, synod (this phenomenon was not infrequent during the synods of earlier epochs). It should also be noted that the rulings of synods that are contained in the acts are quite abundant in terms of quantity, which certainly stems from the need to regulate a vast amount of legislative matters. In addition, synodal acts are characterised by a large degree of detail, especially in areas such as diocesan structures, the faithful, the types and forms of pastoral work, the service of preaching and the service of consecration..$^{39}$ Finally, we should also mention that the synodal legislators consider the particular law that is in force in the Church region (country), which have been adopted by the Episcopal Conference of Poland, among others, the resolutions of the Second Polish Plenary Synod (1991-1999). ${ }^{40}$

In the end resolutions of the synods, two formulas can be identified: a doctrinal-juridical one and a strictly juridical one. In the application of the former, much space is devoted to reminders about the Council teachings, as well as to describing the religious situation of a particular Church, some declarations, indications, etc. are formed, which usually constitute a programme of pastoral renewal. The legislation, on the other hand, has the character of the conclusions that have been drawn from these doctrinal-pastoral arguments. However, in the strictly juridical formula, this doctrinal-sociological layer is completely omitted, and only legal norms are specified. ${ }^{41}$

The most common deficiencies of the acts that are undertaken at synods are placing provisions in the instructions or regulations, when a given matter should be regulated by an act; the inappropriate distribution of the same matter between acts and instructions or regulations; the too wordy formulation of provisions; the lack of proper clarity between instructions that are of an obligatory or optional nature, and a lack of a reference to Canon Code when it is literally placed in an act. ${ }^{42}$ As far as the latter is concerned, it is inappropriate to repeat code provisions and to include them in synodal statutes (a synod is not a collection of common law). This practice may give the impression that the synodal legislation includes the "most important" norms of the CIC and the norms of diocesan law. ${ }^{43}$

\footnotetext{
39 Ibidem.

40 Ibidem.

41 Ibidem, pp. $47-48$.

42 Ibidem.
}

43 The point is that such a "binding" of common law to particular law should not blur the differences between them, nor should it give the impression that the use of a body of laws that are adopted at a synod is sufficient. We should, therefore, not refer 


\section{Expectations towards subsequent synods}

The careful "tracking" of the already numerous Polish diocesan synods that took place after the promulgation of the new CIC and the publication of two important documents on the synods by the Holy See (in 1997 and 2004) enables us to make a number of comments regarding the diocesan legislators. It is about an attempt to outline a vision of a synod that would correspond, in the possibly greatest extent, to what the Code states in the respect that is "enriched" by the dispositions of these documents. This is even more so since the modern diocesan synod - as shown by experience - in many cases does not fully meet the requirements set out in it. Suffice it to say that many synodal assemblies are concluded with a ceremonial liturgy and a promulgation of the end resolutions by the diocesan legislator, then carefully published in the form of a several-hundred-pages-long "synodal book," which eventually becomes a dead letter collecting dust on the shelves of the clergy. The results of the research on the reception of synodal resolutions would certainly be interesting, especially when it comes to the frequency of referring to them by both the diocesan bishop and the diocesan presbytery, not to mention the lay faithful.

Here we can ask: In many cases, isn't the convening of a synod random? Is it not the case that here and there a synodal assembly takes place only because it seems appropriate for the reason that it has already taken place in other dioceses, and that the foregoing suggest simply a contemporary trend? However, the aim is that a diocesan synod should really be both a privileged place to exercise the authority/pastoral service of the diocesan bishop and an effective instrument of a religious-moral and pastoral renewal of the "particle" of the Church that is entrusted to it. In order for this to happen, for a contemporary diocesan synod to fulfill its role, it is necessary to fulfill certain conditions, which apply to all stages of the synodal iter.

First of all, we should remember, and it is reminded to us in the 1997 Instruction of the Congregation for Bishops and the Congregation for the Evangelisation of Nations (hereinafter: Instruction), that a diocesan synod, according to can. 460, is "an assembly of elected priests and other faithful of the particular Church who, for the good of the entire diocesan community, provide assistance to the diocesan bishop." 44

to the provisions of the Code and should limit ourselves only to the formulation of legal norms of a specific nature (with possible references to the appropriate canons).

${ }^{44}$ Congregatio pro Episcopis, Congregatio pro Gentium Evangelizatione: De synodis..., no I. 
The significant moment is the very decision to open a synod and the choice of the issues that are to be addressed in the synodal reflection. The bishop, knowing the needs of his diocese, after a wider consultation (eventually with the Consilium Presbyterale), when he decides on whether to conduct a synod, should decide on its subject matter. This can cover all of the matters of a particular Church, as well as specific areas or even just one thread (e.g. marriage and family or Catholic education). The latter option seems to guarantee a greater effectiveness of the expected result, that is, deepening of the awareness of all of the faithful in a given field. In each case, the diocesan bishop should remember that a synod is to serve "the good of the entire diocesan community" (can. 460), which is also mentioned in the Instruction. ${ }^{45}$

The success of a synod largely depends on the proper preparation of this event. We can distinguish here into long-term and imminent preparation.

The long-term preparation, which should begin with informing the faithful of the diocese (with an occasional pastoral letter sent at the appropriate time) of the bishop's initiative with a call to pray for the intentions of this work. It is important for the bishop to make both the clergy and the laity aware of the importance of this work, as well as members of the institutes of consecrated life and Apostolic associations, with the necessary explanation of the place and role of the synod in the life of a particular Church. At that time, a preparatory commission should already be in place to assist the bishop in undertaking and carrying out the further pre-synodal (mainly organisational) activities; such a commission is mentioned in the Instructions. ${ }^{46}$

As far as the imminent preparation is concerned, this should include, above all, the establishment of the principal commission of the synod by the bishop, his secretariat, the general secretary, the subject commissions (in accordance with the matter(s) proposed by the preparatory commission) and the press office. A glaring mistake (sometimes made) would be to appoint a chairman of the synod who is the diocesan bishop (can. $462 \S 2$ ). When it comes to the composition of these bodies, it would be appropriate to consider the competence of the individuals (e.g. by appointing experts in a given field) and to include lay faithful in these bodies.

An important moment, subsequently, is the preparation of a document that includes the synod regulations, which requires the bishop's approval. The regulations should precisely define everything that con-

\footnotetext{
45 Ibidem.

${ }^{46}$ Ibidem, no. III.
} 
cerns the synodal activities ${ }^{47}$; it is a kind of "guide" on the synodal method.

A synod should be officially opened with a liturgical part and a synodal session (the bishop's speech and several occasional speeches by experts on the institution of synod) at the appropriate time.

Undoubtedly, an important stage of during the synod is the preparation of the drafts of end resolutions by the responsible committees, which requires a great deal of time, and then, a broad consultation of these in the diocese. Therefore, the drafts that are developed by these bodies (after consultation period with the bishop) should be sent to the parish and community synodal groups for discussion and addition of comments. Such a broad consultation should ensure that the idea of the synod that will be realised in these projects will pave the way for the diocesan community as a whole, while at the same time giving them the opportunity to express themselves freely on the crucial issues of the synodal debate. It is not difficult to find here a form of the kind of catechisation that is conducted in relation to all of the diocesans.

The Instruction states that a synod should be composed of synodal sessions. ${ }^{48}$ These play a leading role here because they become the fora for a free and creative exchange of ideas among the participants of the synodal assembly, and thus, they are a special place for an intra-Church dialogue on the scale of a particular Church. It is here, according to the meaning of the Greek word synodeuein, that the diocesan Church creates a "common path" that will lead to a deepening of its own ecclesial consciousness as well as to reform and renewal. The basic plane of understanding on this path is the relationship of the diocesan bishop with the other participants. The direction, pace, and endpoint of this journey is determined by the bishop, who, as the Dogmatic Constitution on the Church Lumen Gentium of the Second Vatican Council states, "by virtue of his office has the sacred right and duty towards the Lord to legislate for his people, to exercise judgment and to direct all that belongs to the fields of worship and the apostolate." 49

If a synod constitutes an effective tool for the development of Church life, it is because it makes the People of God not only the addressees of the bishop's ordinances and directives, but also their subjects. ${ }^{50}$ After all,

${ }^{47}$ See ibidem.

${ }^{48}$ Ibidem, no IV, 1.

${ }^{49}$ Dogmatic Constitution on the Church Lumen gentium, no. 22, in: Sobór Watykański II. Konstytucje, Dekrety, Deklaracje. Polish text. Pallotinum 1967.

${ }^{50}$ See G. Feliciani: "Corresponsabilità ecclesiale nella struttura gerarchica della Chiesa." In: Comunione ecclesiale e strutture di corresponsabilità. Eds. J. BeYer, G. FelICIANI, H. MülLER. Roma 1990, pp. 37-39. 
all of the participants of synod can speak freely in the synodal hall or in the bishop's cathedral. It can be said that in these places, the Church office meets the charismata that are represented by all of those who participate in the Episcopal authority. The legislative activity of the entire diocesan community, whose shepherd chooses the "collegial," or rather, collective form of exercising his potestas legislativa, is actualised here. ${ }^{51}$

The result of the work of a diocesan synod are the end resolutions, which are the synodal decrees and declarations that are signed and promulgated by the diocesan bishop, which means, as the Instruction states, that he is their author. ${ }^{52}$ As was mentioned above, the Instruction explains that these "decrees" should be understood to be the true norms of law. ${ }^{53}$ It should, therefore, be assumed that a synod cannot limit itself to descriptions of facts, statements, encouragements or postulates, but that some of its resolutions should be normative. Of course, this should be borne in mind, first of all, by the bishop.

The legal norms that are adopted at a synod should be adapted to the needs of the dioceses, and all effort should be made to avoid simply repeating the Code provisions, even in the form of paraphrasing them. These are norms that would adapt the common law to the needs of a particular Church, even in the form of their specification. As far as any declarations are concerned, they should be texts in which the thought of a particular Church is presented, which is authoritatively approved by the diocesan bishop with regard to the problems of the moment. ${ }^{54}$ At this point, we can appeal for a far-reaching discipline in the selection and formulation of these texts because they can often be accused of being per abusum.

The declarations and decrees of a synod, which are developed by this synod and recognised as its own by the diocesan bishop, cannot remain on paper alone, otherwise the entire synodal endeavour would be fruitless or even useless. No wonder that the Instruction draws attention to the execution of the final documents, and especially, to the decrees. The responsibility rests with the diocesan bishop, who ought to ensure that the manner in which the resolutions are implemented is determined by the synodal documents themselves or by a separate decree. ${ }^{55}$ It seems appropriate for the diocesan administrator to establish a proper commis-

${ }^{51}$ W. GóRALSKi: "Synod diecezjalny narzędziem odnowy...," p. 483.

52 Congregatio pro Episcopis, Congregatio pro Gentium Evangelizatione: De synodis..., no. V, 3.

53 Ibidem, no $\mathrm{V}, 2$.

54 See G. Corbellini: Il sinodo diocesano..., pp. 159-160.

55 Congregatio pro Episcopis, Congregatio pro Gentium Evangelizatione: De synodis..., no. $\mathrm{V}, 6$. 
sion (with a chairman at the head) to oversee the implementation of what is defined in the synodal documents, especially the decrees.

\section{Final remarks}

The phenomenon of synodality, rooted in the theology of the episcopate and in the theology of the Church as a community part from, obviously, being embedded in the structures of the Church, encompasses particular Churches where synodality is a special way of exercising legislative power by the bishop. The soul of synodality is the community that determines its dynamism. While communio is situated primarily on the ontological-sacramental plane, the synodalitas appears, mostly, on the ecclesiological-structural plane and is sometimes referred to as the "operative structure of a community." ${ }^{66}$ We can say that synodality is a particular expression of community. ${ }^{57}$

Through the diocesan synod, this particular place for exercising legislative power by the shepherd with the broad participation of the entire People of God of a given diocese, the unity of the particular Church, which is heading towards renewal, strengthens. A diocesan synod provides an opportunity to deepen the awareness of its participants that the living organism of a particular Church unites the clergy and laity, which was more broadly revealed by the Second Vatican Council by opening the synodal halls more widely for the latter.

The new model of a diocesan synod that was formed after Vaticanum II was more precisely defined in the post-conciliar CIC, which indicated the objectives and structure of this institution, so important in the life of a particular Church. The Code norms were supplemented by the 1997 Instruction of the Congregation for Bishops and the Congregation for the Evangelisation of Nations, De synodis dioecesanis agendis, and then, the Directory of the Congregation for Bishops Apostolorum successores of 2004.

While the synodal assemblies in the Polish Church that were initiated after the Second Vatican Council mainly focused on understanding the Council teachings, the numerous synods that have been held since the promulgation of the new Code of Canon Law have been focused on adapting the diocesan law to this codification. Even though the code

${ }^{56}$ P. Amenta: "Il sinodo diocesano quale organo di partecipazione alla potestà legislativa del vescovo." Periodica 84 (1995), p. 641.

${ }^{57}$ See E. Corecco: "Struttura sinodale o democratica della chiesa particolare?" In: Miscellanea en honor de J. Becerril y A. Miralles. Madrid 1974, pp. 269-299. 
norms have already found their significant reflection in the legislation of particular Churches, the synodal activity continues.

The analysis of the end resolutions that have recently been concluded by the diocesan synods shows that these resolutions leave much to be desired, not only with regard to their very profile, but also in other areas. What constitutes another problem is the implementation of the synodal resolutions and the resulting phenomenon of the relatively "short life" of synods.

\section{Bibliography}

Amenta P.: “Il sinodo diocesano quale organo di partecipazione alla potestà legislativa del vescovo.” Periodica 84 (1995), pp. 639-651.

Coccopalmerio F.: "Il sinodo diocesano (can. 460-468).” In: Raccolta di scritti in onore di Pio Fedele. Perugia 1984, pp. 407-416.

CODEX IURIS CANONICI auctoritate Ioannis Pauli PP. II promulgatus, AAS 75/II (1983); Polish text: Codex Iuris Canonici auctoritate Ioannis Pauli PP. II promulgatus. Code of Canon Law. Polish translation accepted by the Polish Episcopal Conference. Pallotinum 1984.

Congregatio Pro Episcopis: Direttorio per il ministero pastorale dei vescovi "Apostolorum Successores" (22.02.2004), Città del Vaticano 2004; Polish text: CONGREgATION OF BISHOPS: "Dyrektorium Apostolorum successors o pasterskiej posłudze biskupów.” In: Ustrój hierarchiczny Kościoła. Wybór źródet. Ed. W. Kacprzyk, M. Sitarz, Lublin 2006, pp. 517-711.

Congregatio pro EPiscopis, Congregatio Pro Gentium EVANGelizatione: De synodis dioecesanis agendis Instructio (7.07.1997). AAS 89 (1997), pp. 706-727.

Corbellini G.: Il sinodo diocesano nel nuovo Codex Iuris Canonici. Roma 1986.

Corecco E.: "Ius universale — ius particolare." In: Ius in Vita et in Missione Ecclesiae. Acta Simposii Internationalis Iuris Canonici occurente X Anniversario Promulgationis Codicis Iuris Canonici Diebus 19-24 Aprilis 1993 in Civitate Vaticana Celebrati. Libreria Editrice Vaticana 1994, pp. 551-574.

Corecco E.: "Struttura sinodale o democratica della chiesa particolare." In: Miscellanea en honor de J. Becerril y A. Miralles. Madrid 1974, pp. 269-299.

"Dekret O pasterskich zadaniach biskupów w Kościele Christus Dominus." no. 36. In: Sobór Watykański II. Konstytucje, Dekrety, Deklaracje. Polish text, Pallotinum 1967.

Feliciani G.: "Corresponsabilità ecclesiale nella struttura gerarchica della Chiesa." In: Comunione ecclesiale e strutture di corresponsabilità. Eds. J. BEYER, G. Feliciani, H. Müller. Roma 1990, pp. 37-51.

GórAlski W.: "Charakterystyka i ocena II Polskiego Synodu Plenarnego i współczesnych synodów diecezjalnych w Polsce.” In: II Polski Synod Plenarny a synody diecezjalne. Eds. J. Krukowski, M. Sitarz, A. Pastwa. Lublin 2015 , pp. $23-51$. 
Góralski W.: “Instytucja synodu w Kodeksie Prawa Kanonicznego Jana Pawła II.” Prawo Kanoniczne 31 (1988), nos. 3-4, pp. 35-44.

Góralski W.: Wprowadzenie do historii ustawodawstwa synodalnego $w$ Polsce. Lublin 1991.

Góralski W.: “Czy synody są nadal szansą dla Kościoła?” Homo Dei 61 (1992), nos. $1-2$, pp. $1-8$.

GórAlski W.: “Synod diecezjalny narzędziem odnowy i reformy Kościoła partykularnego.” Kronika Diecezji Sandomierskiej 89 (1996), pp. 472-487.

GórAlsKi W.: “Ruch synodalny w Polsce po Soborze Watykańskim II.” Roczniki Nauk Prawnych 8 (1998), pp. 239-261.

GóRALSKI W.: "Ecclesia semper reformanda. W nurcie synodów polskich wczoraj i dziś.” In: Oddanie i wytrwałość. Recepcja II Polskiego Synodu Plenarnego. Eds. W. Góralski, H. Seweryniak. Warszawa 2004, pp. 41-70.

GręźLIKOwsKi J.: “Instytucja synodu diecezjalnego w Kościele w Polsce po Soborze Watykańskim II.” Studia Włocławskie 4 (2001), pp. 107-126;

Konstytucja dogmatyczna o Kościele “Lumen gentium”, no. 22. In: Sobór Watykański II. Konstytucje, Dekrety, Deklaracje. Tekst polski. Pallotinum 1967.

LONGHITANO A.: "I sinodi regionali e diocesani: esperienze e prospettive." In: La sinodalité la participation au gouvernement dans l'Église. Actes du VII Congrès International de Droit Canonique, Paris, Unesco, 21-28 septembre 1990, L’Anné Canonique, hors série (1990), v. 2, pp. 613-622.

Pawluk T.: Prawo kanoniczne wedtug Kodeksu Jana Pawła II, v. 1: Zagadnienia wstępne i normy ogólne. Olsztyn 1985.

Pieronek T.: "Posoborowe synody diecezjalne w Polsce." In: Stużyć Prawdzie i Miłości. Pamięci Księdza Biskupa Dr. Stefana Baryły, III Ordynariusza Częstochowskiego. Ed. J. Kowalski. Częstochowa 1984, pp. 392-412.

Pistocchi M.: De synodo diocesana. Taurini 1922.

SACRA CONGREgATIO PRO EPISCOPIS: Directorium de pastorali ministerio "Ecclesiae imago" (22.02.1973). Typis Polyglottis Vaticanis 1973; Polish text: KonGREGACJA BISKUPÓw: Dyrektorium „Ecclesiae imago” na temat pasterskiej postugi biskupów. In: Posoborowe prawodawstwo kościelne (dokumenty prawno-liturgiczne). Prep. E. SzTafrowski, v. 6, p. 1. Warszawa 1975, pp. 15-352 and in: Ustrój hierarchiczny Kościoła. Wybór źródeł, eds. W. KaCPRzyK, M. Sitarz, Lublin 2006, pp. 403-516.

Sitarz M.: "Podstawowe zasady w sprawowaniu władzy ustawodawczej biskupa diecezjalnego.” In: II Polski Synod Plenarny a synody diecezjalne. Eds. J. KruKowski, M. Sitarz, A. Pastwa. Lublin 2015, pp. 93-117.

Sobański R.: Nauki podstawowe prawa kanonicznego. Teoria prawa kanonicznego, v. 1. Warszawa 2001.

Sztafrowski E.: Podręcznik prawa kanonicznego, t. 1. Warszawa 1985.

SzTAFrowski E.: "Synod diecezjalny w doktrynie soborowej i jej wyraz w posoborowych synodach polskich." Prawo Kanoniczne 30 (1987), no. 1-2, pp. $61-75$.

Wójcik W.: "Synod diecezjalny w nowym Kodeksie Prawa Kanonicznego.” Prawo Kanoniczne 29 (1986), nos. 1-2, pp. 93-122. 
WOJCIECH GóRALSKI

Le synode diocésain aujourd'hui — sous quelle forme?

Résumé

Le Concile Vatican II a créé un nouveau modèle de synode diocésain, qui a été adopté, entre autres, en Pologne, et qui se caractérise par le renoncement à l'établissement de normes de droit particulier et par la diffusion de la doctrine conciliaire dans les Églises particulières. Après la promulgation du nouveau Code de droit canonique en 1983, les synodes diocésains, à leurs tours, ont adapté le droit diocésain aux normes du code. Lorsque cette période de réception de du droit de code à la législation diocésaine a atteint son résultat, les résolutions finales des synodes diocésains ultérieurs, en règle générale étendues, ne répondent pas - dans une large mesure - aux exigences des documents du Saint-Siège: l'Instruction de la Congrégation pour les évêques et la Congrégation pour l'évangélisation des nations de 1997 et aussi le Directoire de la Congrégation pour les évêques Apostolorum successores de 2004. L'auteur de l'article insiste sur le besoin de suivre les dispositions de ces énonciations, afin que les synodes diocésains puissent être un outil efficace pour le renouvellement de l'Église particulière.

Mots clés: synode diocésain, législation, arrêté synodal, évêque diocésain

WOJCIECH GóRALSKI

Sinodo diocesano oggi: in quale forma?

\section{Sommario}

Il Concilio Vaticano II ha creato un nuovo modello di sinodo diocesano, che è stato adottato, tra l'altro in Polonia, e che è caratterizzato dalla rinuncia allo stabilire le norme del diritto particolare e dalla diffusione della dottrina conciliare nelle chiese particolari. Dopo la promulgazione, nel 1983, del nuovo Codice di Diritto Canonico, i Sinodi diocesani, a loro volta, hanno adattato il diritto diocesano alle norme del codice. Quando quel periodo di ricezione della legge di codice dalla legislazione diocesana ha raggiunto il suo risultato, le risoluzioni finali dei sinodi diocesani successivi, di regola di ampie dimensioni, non soddisfano - in larga misura - i requisiti dei documenti della Santa Sede: l'Istruzione della Congregazione per i vescovi e la Congregazione per l'evangelizzazione delle nazioni del 1997 e anche il Direttorio della Congregazione per i vescovi Apostolorum successores del 2004. L'autore dell'articolo insiste sul bisogno di seguire le disposizioni di queste enunciazioni, affinché i sinodi diocesani possano essere uno strumento efficace per il rinnovamento della Chiesa particolare.

Parole chiave: sinodo diocesano, legislazione, risoluzioni sinodali, vescovo diocesano 